\title{
Rare Initial Presentation of Acute Myeloid Leukemia as Facial Palsy
}

Sir,

Granulocytic sarcoma is an extramedullary collection of immature myeloid cells in bone and soft tissues which may occur at any site in the body. Facial palsy due to granulocytic sarcoma in the temporal bone as the first presentation of acute myeloid leukemia (AML) is rare. Diagnosis of leukemia at first may be difficult as blast cells may appear in blood after an interval of weeks to months of initial presentation.

A 6-year-old boy presented with sudden onset right side facial weakness and facial asymmetry for 2 months. The patient had received a course of oral steroids without any improvement in facial asymmetry. He had a history of common cold and bilateral ear ache preceding the facial weakness. At presentation, he had right-sided House-Brackmann grade 4, lower motor neuron type facial palsy. Ear examination showed right-sided dull tympanic membrane with some bulge in posterosuperior quadrant and left-sided dull pars tensa. Tuning fork test suggested bilateral conductive hearing loss which was more on the right side. Rest of the nose, throat and neck examination was insignificant. All blood investigations were normal including peripheral blood smear. High-resolution computed tomography (HRCT) of temporal bone showed soft-tissue density in middle ear, attic, aditus, and mastoid air cells with intact ossicles suggestive of bilateral mastoiditis [Figure 1a]. Hence, a provisional diagnosis of right-sided subacute otitis media with mastoiditis and facial palsy was made.

The patient was started on parenteral antibiotics and was taken up for mastoid exploration. Intraoperatively periantral cells, antrum, aditus, and attic were filled with granulations and pale, soft yellowish globular tissue [Figure 1b] which was sent for histopathology. All ossicles were intact and mobile. The aditus was made patent by removing incus and hypertrophic mucosa. Middle ear mucosa was hypertrophic. The fallopian canal was intact throughout. Cortical mastoidectomy was performed, and the patient 
was given oral antibiotics for another week. Facial nerve palsy improved to grade 2 after 3 weeks following surgery [Figure 2a and b]. Histopathology of the sent soft tissue revealed many immature cells (blasts admixed with eosinophils and eosinophils precursors) which were immunopositive for CD34, MPO, and Tdt (focal) while negative for CD3, CD20, CD1a, and langerin. The overall picture suggested infiltration by leukemic blast cells [Figure 3]. As peripheral smear was normal, a bone marrow aspiration was performed which showed $\mathrm{t}(8: 21)$ along with $7 \%$ blast cells. Hence, a diagnosis is made and patient started on chemotherapy. His facial weakness resolved completely during chemotherapy.

Facial palsy may be seen in $1 \%$ of leukemia patients. ${ }^{[1]}$ Facial palsy along with middle ear and mastoid infection as the initial symptom in leukemia cases has been reported only in six cases. ${ }^{[2,3]}$ It may also be a symptom of relapse of leukemia after treatment. It is proposed that facial palsy may be due to direct infiltration of leukemic cells or due to infection. The blast cells may be apparent in peripheral circulation months to years after the initial symptom. ${ }^{[3]}$ Thus in pediatric patients with unilateral or bilateral facial palsy, lymphoproliferative disorders should always be kept in the differential diagnosis. Furthermore, Bell's palsy is uncommon in pediatric patients.

The overall HRCT finding in granulocytic sarcoma of temporal bone closely mimics acute mastoiditis. ${ }^{[4]}$ Granulocytic sarcoma is an extramedullary collection of leukemic blasts, and its incidence in temporal bone is $3.1 \%-6.8 \% .^{[5]}$ Leukemic cells may infiltrate the dehiscent facial nerve, and therefore, facial nerve decompression is not recommended except when the tumor tissue seems compressing the facial nerve. ${ }^{[2]}$

Granulocytic sarcoma is most commonly seen in AML type M2 FAB classification with 8:21 translocation and has a preference for cranial and facial bones. Thirty eight percent of them have the previous history of AML. ${ }^{[3]}$ Complete hematological and radiological workup must be performed in pediatric patients presenting with acute facial palsy so as to detect these lymphoproliferative disorders at an early stage. Atypical tissue seen during surgery for mastoiditis must been sent for histopathological examination. Follow-up is necessary as there may be a time lag between initial symptoms and the appearance of blast cells. Early diagnosis and early initiation of chemotherapy influences the overall disease prognosis.

\section{Declaration of patient consent}

The authors certify that they have obtained all appropriate patient consent forms. In the form, the patient's parents have given his consent for his images and other clinical information to be reported in the journal. The patient's parents understand that name and initials will not be published, and due efforts will be made to conceal identity, but anonymity cannot be guaranteed.
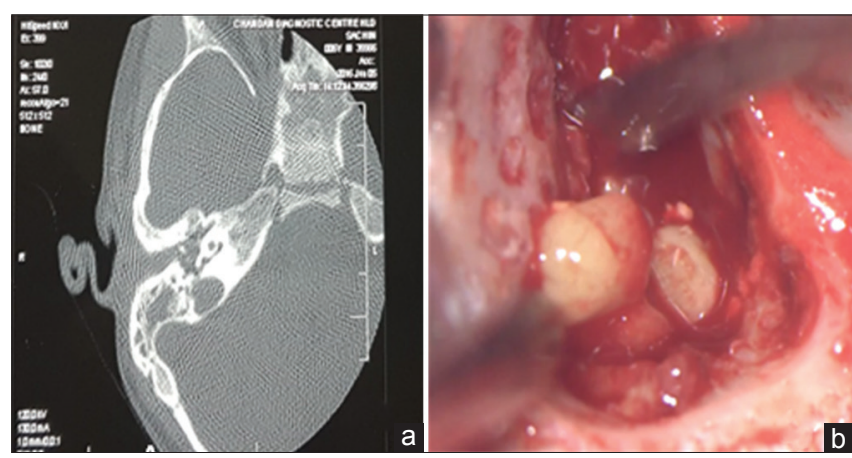

Figure 1: (a) High-resolution computed tomography scan showing axial cut through right ear, (b) intraoperative mastoid antrum showing globular yellowish tissue

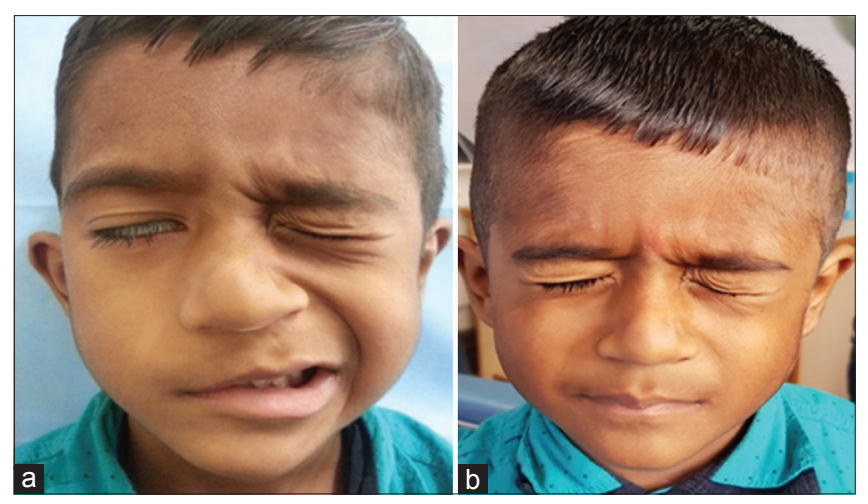

Figure 2: Showing pre (a) and post (b) surgery clinical picture of the patient, respectively, reproduced with parenteral consent

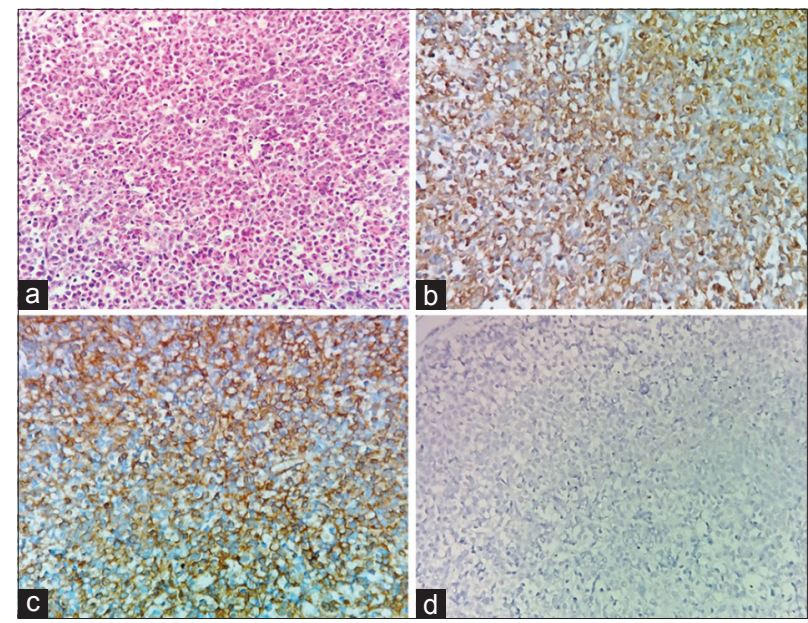

Figure 3: Photomicrograph showing sheets of immature cells (blasts) admixed with eosinophilic precursors (a: H and E, $\times 400)$. The blasts are immunopositive for CD 34 and myeloperoxidase (b and c: IHC, ×400), while are negative for langerin (d: IHC, $\times 400)$

\section{Financial support and sponsorship}

Nil.

\section{Conflicts of interest}

There are no conflicts of interest.

\section{Shilpi Budhiraja, Prem Sagar, Madhu Rajeshwari ${ }^{1}$, Rajeev Kumar}


Departments of Otorhinolaryngology and Head and Neck Surgery and ${ }^{I}$ Pathology, All India Institute of Medical Sciences, New Delhi, India

Address for correspondence: Dr. Prem Sagar,

Department of Otorhinolaryngology and Head and Neck Surgery, All India Institute of Medical Sciences, New Delhi - 110 029, India. E-mail: sagardrprem@gmail.com

\section{References}

1. Lee B, Fatterpekar GM, Kim W, Som PM. Granulocytic sarcoma of the temporal bone. AJNR Am J Neuroradiol 2002;23:1497-9.

2. Todd NW Jr., Bowman CA. Acute myelogenous leukemia presenting as atypical mastoiditis with facial paralysis. Int $\mathrm{J}$ Pediatr Otorhinolaryngol 1984;7:173-7.

3. Bilavsky E, Scheuerman O, Marcus N, Hoffer V, Garty BZ. Facial paralysis as a presenting symptom of leukemia. Pediatr Neurol 2006;34:502-4.

4. Ooi GC, Chim CS, Khong PL, Au WY, Lie AK, Tsang KW, et al. Radiologic manifestations of granulocytic sarcoma in adult leukemia. AJR Am J Roentgenol 2001;176:1427-31.

5. Almadori G, Del Ninno M, Cadoni G, Di Mario A, Ottaviani F. Facial nerve paralysis in acute otomastoiditis as presenting symptom of FAB M2, T and 21 leukemic relapse. Case report and review of the literature. Int $\mathrm{J}$ Pediatr Otorhinolaryngol 1996;36:45-52.

This is an open access journal, and articles are distributed under the terms of the Creative Commons Attribution-NonCommercial-ShareAlike 4.0 License, which allows others to remix, tweak, and build upon the work non-commercially, as long as appropriate credit is given and the new creations are licensed under the identical terms.

\begin{tabular}{|l|l|}
\hline \multicolumn{2}{|c|}{ Access this article online } \\
\hline Quick Response Code: & Website: \\
& www.ijmpo.org \\
\cline { 2 - 2 } & DOI: \\
\hline
\end{tabular}

How to cite this article: Budhiraja S, Sagar P, Rajeshwari M, Kumar R. Rare initial presentation of acute myeloid leukemia as facial palsy. Indian J Med Paediatr Oncol 2018;39:555-7.

C 2018 Indian Journal of Medical and Paediatric Oncology | Published by Wolters Kluwer - Medknow 